\title{
Fabrication and Characterization of YSZ/ScSZ bilayer electrolyte via Cold- Isostatic Pressing (CIP) Method for Intermediate Temperature-Solid Oxide Fuel Cell (IT-SOFC) Application.
}

\author{
Zuraida Awang Mat ${ }^{1, *}$, Shri Kumaran Nadaraja ${ }^{1}$, Zulfirdaus Zakaria ${ }^{1}$, Saiful \\ Hasmady Abu Hassan ${ }^{2}$, Yap Boon Kar ${ }^{2}$, Chou Yong Tan ${ }^{3}$, Mahendra Rao \\ Somalu ${ }^{4}$
}

${ }^{1}$ Institute of Sustainable Energy, Universiti Tenaga Nasional, Jalan Ikram-Uniten, Kajang, 43000, Selangor, MALAYSIA.

${ }^{2}$ College of Engineering, Universiti Tenaga Nasional, Jalan Ikram-Uniten, Kajang, 43000, Selangor, MALAYSIA.

${ }^{3}$ Department of Mechanical Engineering, Faculty of Engineering, University of Malaya, 50603 Kuala Lumpur, MALAYSIA.

${ }^{4}$ Fuel Cell Institute, Universiti Kebangsaan Malaysia, 43600 UKM Bangi, Selangor, MALAYSIA.

*Corresponding Author

DOI: https://doi.org/10.30880/ijie.2019.11.07.026

Received 16 July 2019; Accepted 20 October 2019; Available online 15 November 2019

\begin{abstract}
Solid oxide fuel cell (SOFC) technology has advanced significantly in the recent years, and now is an interest of many renewable energy-related industries to invest. However, the main issue of SOFC is the high operating temperature that negatively influence its performance. To reduce the temperature, a method of using bilayer electrolyte is proposed. In this study, a bilayer electrolyte of Yttria-Stabilised Zirconia (YSZ) and ScandiaStabilized Zirconia (ScSZ) is used with the objective to reduce the temperature of SOFC to intermediate temperature ranges. To achieve the objective, bilayer YSZ/ScSZ electrolyte has been fabricated at different compositions using cold-pressing method. The pellets were sintered at three different temperature of $1350{ }^{\circ} \mathrm{C}, 1450$ ${ }^{\circ} \mathrm{C}$ and $1550{ }^{\circ} \mathrm{C}$. In this studies, all the prepared pellets were characterized under Scanning Electron Microscopy (SEM) to examine its microstructure, Archimedes Method to measure the density and Electochemical Impedance Spectroscopy (EIS) to measure the conductivity. The results show that all of produced pellets are dense and ionic conductivity showed a rising trend as sintering temperature increases. Based on this study, the best composition is the pellet with combination of $25 \% \mathrm{YSZ}: 75 \% \mathrm{ScSZ}$ sintered at $1450{ }^{\circ} \mathrm{C}$.
\end{abstract}

Keywords: IT-SOFCs; Bilayer Electrolyte; YSZ/ScSZ electrolyte; Fuel Cells

\section{Introduction}

Few century ago, the research on fuel cell [1], which a device that convert chemical energy to electrical energy start to kick in [2]. One of the many types of fuel cells that gain popular interest is the one that have hard ceramics electrolyte, Solid Oxide Fuel Cell (SOFC) [3]. A solid oxide fuel cell (SOFC) is an energy conversion device that 
operates when fuel is combined with an oxidant across an ionic conducting oxide electrolyte to produce electricity. SOFCs are considered ideal for power generation systems as they are reliable, efficient, environmental friendly and fuel saving. SOFC systems can be found in portable devices, small power systems to independent generation power plants. Integration of SOFC [4] with a gas turbine make it possible to form pressurized hybrid power plant systems of several hundred $\mathrm{kW}$ to multi-MW [5]. Power generation systems of sizes up to $250 \mathrm{~kW}$ have been using tubular type SOFCs [6]. Supposedly, for SOFC that using YSZ as its electrolyte, the operating temperature must be very high which is up to $1000{ }^{\circ} \mathrm{C}$ in order to obtain high ionic conductivity. For high operational temperature, however, there are a few limitation in applications such as transportation, stationary and power plant. The challenges of having high operating temperature included mechanical stress, material thermal stress and slower start-up time [7].

To further improve long-term performance stability and widen choice of materials, it is suggested to decrease the current operating temperature of SOFCs from $1000{ }^{\circ} \mathrm{C}$ to an intermediate/low-temperature range of $400{ }^{\circ} \mathrm{C}-600{ }^{\circ} \mathrm{C}$. Potential problems that might hinder the performance and fabrication of intermediate/low temperature SOFCs known to be the overall increase of cell electrolyte resistance and high electrode over-potentials. The first solution is to lower the thickness of the electrolyte [8]-[10]. Next is substituting the electrolyte with one with higher ionic conductivity at lower temperatures [8], [9], [11], [12]. A bilayer electrolyte may also solve this issue by acting as a method to block the flow of electronic current and improve the open-circuit voltage[13]. Therefore, a higher ionic conductivity can be achieved through the usage of layering. Combinations of bilayers include but not limited to YSZ/GDC (Yttriastabilized zirconia/Gadolinium-doped ceria), YSZ/ScSZ (Yttria-stabilized zirconia/Scandia-stabilized zirconia) and ESB/ SDC (Stabilized Bismuth Oxide /Samaria-doped ceria). Over the years, many performance evaluations show that higher ionic conductivity of bilayer electrolyte produced better power densities that would be able to operate at intermediate temperatures[14]-[18]. Upon reviewing many materials used as SOFC electrolyte, a study shows ScSZ exhibit the highest reading in electrical conductivity in the electrolytic region with similar ionic conductivity value of YSZ electrolytes [18]. Scandia-Stabilised Zirconia offers much higher conductivity than Yttria- Stabilised Zirconia at $1000^{\circ} \mathrm{C}$ with a bigger chances of enhancement at lower temperature due to its low activation energy. This allows the operating temperatures of SOFCs with ScSZ bilayers can be further lowered. In recent studies [19]-[22], ScandiaStabilized Zirconia is a suitable electrolyte material to use in Intermediate-Temperature of SOFCs compare to other materials. A few researchers such as Badwal, Spirin and Laguna [23]-[25] are all highlighted about the important of Scandia-Stabilized Zirconia in IT-SOFCs developments.

Therefore, a YSZ/ScSZ bilayer can provide both phase and chemical stability while have superior ionic conductivity compared to other bilayer combinations to operate in low temperatures [11], [14]-[16], [26], [27]. This shows many researchers are suggesting that bi-layered electrolyte material is a solution for intermediate temperature SOFC operation. The base electrolyte material should have high ionic conductivity and occupies the most of the electrolyte thickness. Also, the functional electrolyte material should supplement the demerits of the main material and thinner. A highly conductive electrolyte material and functional layer structure should be selected to lower the operating temperature and prevent chemical instability [26]. Previous studies show that in most cases, YSZ has been paired with ceria-based materials such as GDC [28], [29] and SDC [28], [30] as base layer. There are also studies of bilayering YSZ with ScSZ material, however the layer designs were manufacture via tape-casting and spray coating [26].

Based on these previous studies, the present study aimed to investigate the effect of bilayer ScSZ/YSZ electrolyte of different compositions using cold-pressing method. This paper also investigate the effect of three different sintering temperature of $1350{ }^{\circ} \mathrm{C}, 1450{ }^{\circ} \mathrm{C}$ and $1550{ }^{\circ} \mathrm{C}$ on the microstructure, density and electrochemical properties of YSZ/ScSZ bilayer electrolyte. The best compositions and temperatures (operating and sintering) of bilayer YttriaStabilized zirconia and Scandia-Stabilized zirconia electrolyte are evaluated. Besides, this study also aimed to improve fabrication method via cold-pressing method which should reduce time of sintering and enhance the electrochemical performance of the electrolyte.

\section{Experimental Procedures}

\subsection{Design \& Fabrication}

Figure 1 shows the design layer of YSZ/ScSZ pellets that were considered for fabrication in this work. There are five (5) weight ratio being varied in this experiment which are (i) $100 \% \mathrm{YSZ}$, (ii) $25 \% \mathrm{YSZ}$ : $75 \% \mathrm{ScSZ}$, (iii) $50 \% \mathrm{YSZ}$ : 50\%ScSZ, (iv) 75\%YSZ: 25\%ScSZ and (v) 100\% ScSZ. The YSZ/ScSZ bilayer electrolyte was fabricated using manual pressed and cold-pressed method. The commercial powders of both YSZ and ScSZ are obtained from FuelCellMaterial.com, USA and has a Brunauer-Emmett-Teller (BET) surface area of $13.4 \mathrm{~m}^{2} / \mathrm{g} \mathrm{and} 10.6 \mathrm{~m}^{2} / \mathrm{g}$, respectively. The particle size of ScSZ powder is $0.53 \mu \mathrm{m}$ while the average particle size of YSZ powder is around $0.5 \sim 0.7 \mu \mathrm{m}$. The supplier did not give specific specification of particle size of YSZ powder.

The bilayer electrolyte pellets were prepared by weighing the commercial YSZ and ScSZ in weight ratio of 50:50. The 50YSZ: 50ScSZ powder was then manual pressed at $4 \mathrm{MPa}$ into cylindrical pellets with a 20 mm diameter and 3 $\mathrm{mm}$ thickness via a manual die-pressing bench. This process was repeated for other weight ratio. All prepared pellets were then cold-pressed via CIP method. During cold-pressing, oil is used as the pressurized medium. The oil is pressed into a sealed high-pressure steel container by using a high-pressure pump. The resulting high pressure will be applied to 
the powders in the elastic mold isotropically at the same time. Since friction from powder/powder, powders/mold wall is small enough, a dense, crack free and well-bonded YSZ-ScSZ bilayer will be produced. All pellets were sintered respectively at $1350{ }^{\circ} \mathrm{C}, 1450{ }^{\circ} \mathrm{C}$ and $1550{ }^{\circ} \mathrm{C}$ for 2 hours.

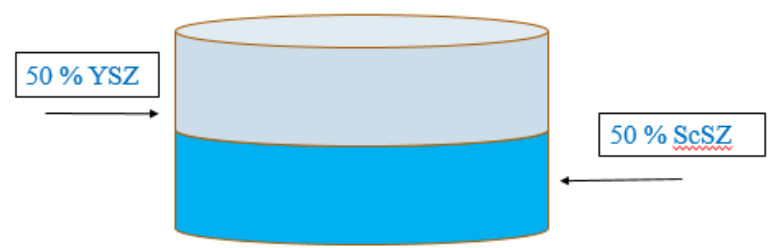

Figure 1 - Design of bi-layer electrolyte for the case of 50 YSZ and $50 \mathrm{ScSZ}$.

\subsection{Characterization}

The density of the pellets was determined via the Archimedes' Principle using deionized water at room temperature. Archimedes' Principle were used to determine the density of porous ceramic materials. An analytical balance was used in this work. The density of the pellets was calculated as per Equation 2-1:

$$
\rho=\frac{M}{M-M W} x \ldots
$$

Where $\rho$ is the density of pellet, $M$ is the weight of the pellet in air (dry), $M w$ is the weight of pellet immersed in distilled water and $\rho w$ is the density of water taken as $0.99677 \mathrm{~g} / \mathrm{cm}^{3}$. The relative density was then calculated through dividing the determined density by calculated theoretical density of both Yttria-Stabilised Zirconia ceramics (6.01 $\mathrm{g} / \mathrm{cm} 3)$ and Scandia-Stabilised Zirconia $\left(5.89 \mathrm{~g} / \mathrm{cm}^{3}\right)$. For the bilayer density calculation, the Equation $2-2$ is referred:

$$
\rho b x=\frac{M y s z+M s \cos z}{V \operatorname{tot} \alpha l}
$$

Where $\rho b$ is the density of bilayer, Mysz is the weight of the YSZ pellets composition in weight ratio percentage, Mscsz is the weight of the ScSZ pellets composition in weight ratio percentage. Vtotal is as per Equation 2-3:

$$
\text { Vtatal }=V_{y s z}+V_{s c s z}
$$

where Vtotal is total volume of bilayer, Vysz is volume value of YSZ and Vscsz is volume value of ScSZ. The samples then were studied under Scanning Electron Microscopy (SEM) to examine the microstructure and particle size. The conductivities of the pellets were measured from $800^{\circ} \mathrm{C}-500^{\circ} \mathrm{C}$ using electrochemical impedance spectroscopy (EIS). EIS was used in a two terminal setup and silver paste were applied to both sides of the sintered pellets. The pellets then heated up to $800{ }^{\circ} \mathrm{C}$ for 1 hour in order for the silver paste to dry. The purpose of the silver electrode area were to determine the final conductivity. With a flow of compressed air at $100 \mathrm{ml} / \mathrm{min}$, testing operating temperature were measured from $800{ }^{\circ} \mathrm{C}-500{ }^{\circ} \mathrm{C}$ with $50{ }^{\circ} \mathrm{C}$ intervals. A frequency response analyzer Autolab was used to help at present measuring the ionic conductivity.

\section{Result and Discussion}

\subsection{Density Test of Pellets}

Table 1 presents the result of the relative density measurement. Based on the calculated data, it all produced pellets are dense and well-bonded with relative density of $95-97 \%$. This value are comparable with the values reported in the literature [31]. According to previous reports [32], [33], this value of relative density is acceptable for porous ceramic electrolyte. This proved that the cold-pressed method is suitable in fabricating ceramic bi-layer electrolyte materials.

\subsection{Electrochemical Impedance Spectroscopy (EIS) Analysis}

The effect of sintering temperature and bilayer compositions on the ionic conductivity of the bilayer electrolyte pellets was measured via EIS. Arrhenius' Law was used to interpret the ionic conductivity data and plots natural logarithm of the conductivity values against the inverse of temperature in degree Kelvin. The Arrhenius Equation 3-1 used are as follows: 


$$
\sigma \mathrm{T}=\mathrm{A} \exp \left(-\mathrm{E}_{\mathrm{a}} / k \mathrm{~T}\right)
$$

where,

$\mathrm{A}$ is the pre-exponential factor,

$E_{a}$ is the activation energy $(\mathrm{eV})$,

$k$ is the Boltzmann's constant $\left(8.617 \times 10^{-5} \mathrm{eV} / \mathrm{K}\right)$, and

$\mathrm{T}$ is the absolute temperature $(\mathrm{K})$.

Table 1 - The relative density of the pellets based on sintering temperature and its bilayer composition.

\begin{tabular}{llllll}
\hline $\begin{array}{l}\text { Sinterin } \\
\begin{array}{l}\text { Temp } \\
\left({ }^{\circ} \mathbf{C}\right)\end{array}\end{array}$ & $\mathbf{1 0 0}$ YSZ & $\mathbf{7 5 Y S Z / 2 5 S c S Z}$ & $\begin{array}{l}\text { Bilayer } \\
\text { Composition } \\
\mathbf{5 0 Y S Z / 5 0 S c S Z}\end{array}$ & $\mathbf{2 5 Y S Z / 7 5 S c S Z}$ & $\mathbf{1 0 0}$ ScSZ \\
\hline 1350 & $95 \%$ & $96 \%$ & $95 \%$ & $95 \%$ & $93 \%$ \\
1450 & $96 \%$ & $96 \%$ & $95 \%$ & $95 \%$ & $95 \%$ \\
1550 & $95 \%$ & $95 \%$ & $97 \%$ & $96 \%$ & $96 \%$ \\
\hline
\end{tabular}

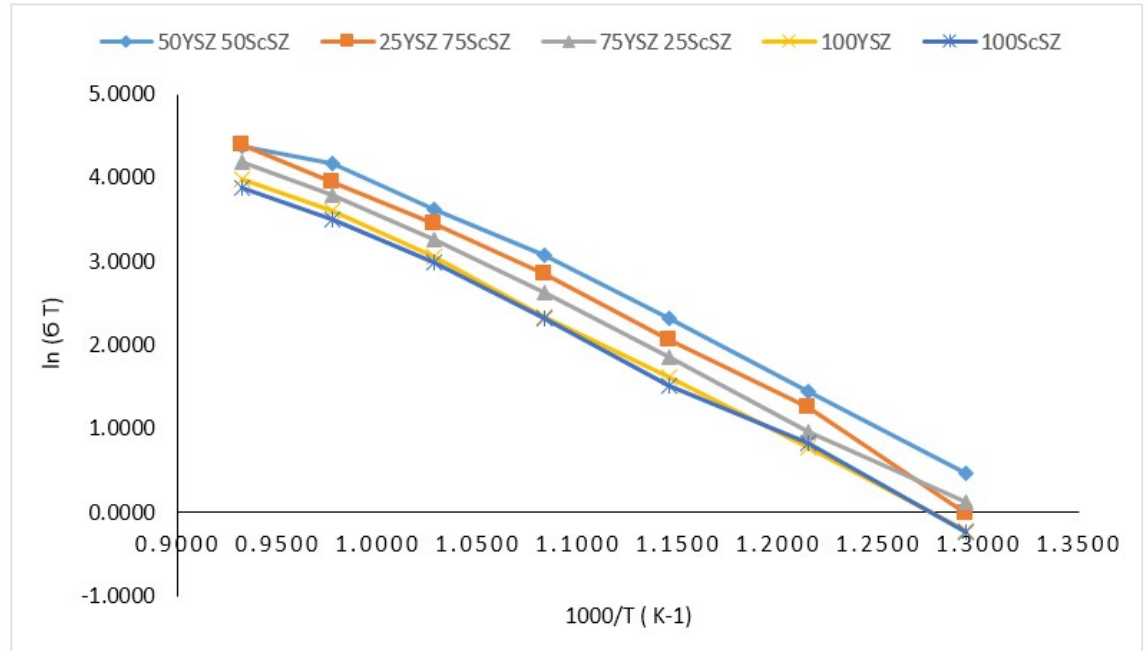

Figure 2 - Arrhenius plots under $1350{ }^{\circ} \mathrm{C}$ sintering temperature

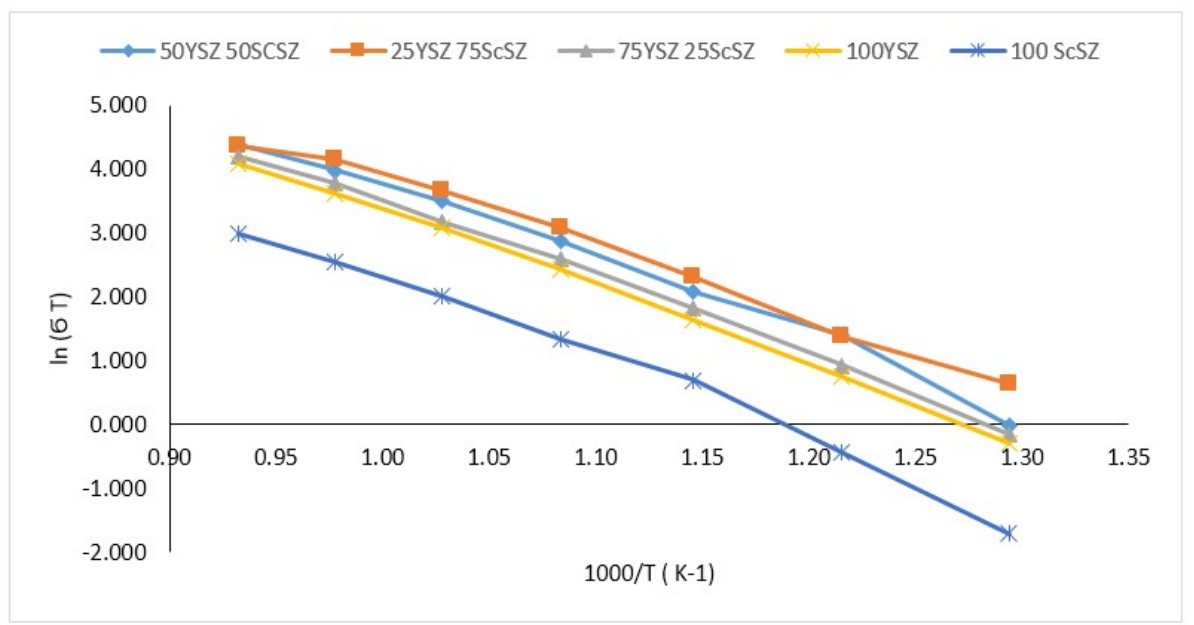

Figure 3 - Arrhenius plots under $1450{ }^{\circ} \mathrm{C}$ sintering temperature

Figure 2 shows that the pellets with $50 \mathrm{YSZ}$ : $50 \mathrm{ScSZ}$ ratio has the highest ionic conductivity after being subjected to sintering temperature of $1350^{\circ} \mathrm{C}$. However, the ionic conductivity for this ratio of $50 \mathrm{YSZ}$ : $50 \mathrm{ScSZ}$ were the second highest after being subjected to sintering temperature of $1450^{\circ} \mathrm{C}$ and continue to drop to the third when being subjected to sintering temperature of $1550{ }^{\circ} \mathrm{C}$. From this observation, we speculated that the presence of pores in this 50YSZ: 
$50 \mathrm{ScSZ}$ pellet is the cause for the low ionic conductivity. There might be impurities formed during fabrication process that can cause formation of pores at the grain boundaries when subjected to high sintering temperature. Hence, it can be concluded that $50 \mathrm{YSZ}$ : $50 \mathrm{ScSZ}$ ratio is best performing at sintering temperature of $1350^{\circ} \mathrm{C}$.

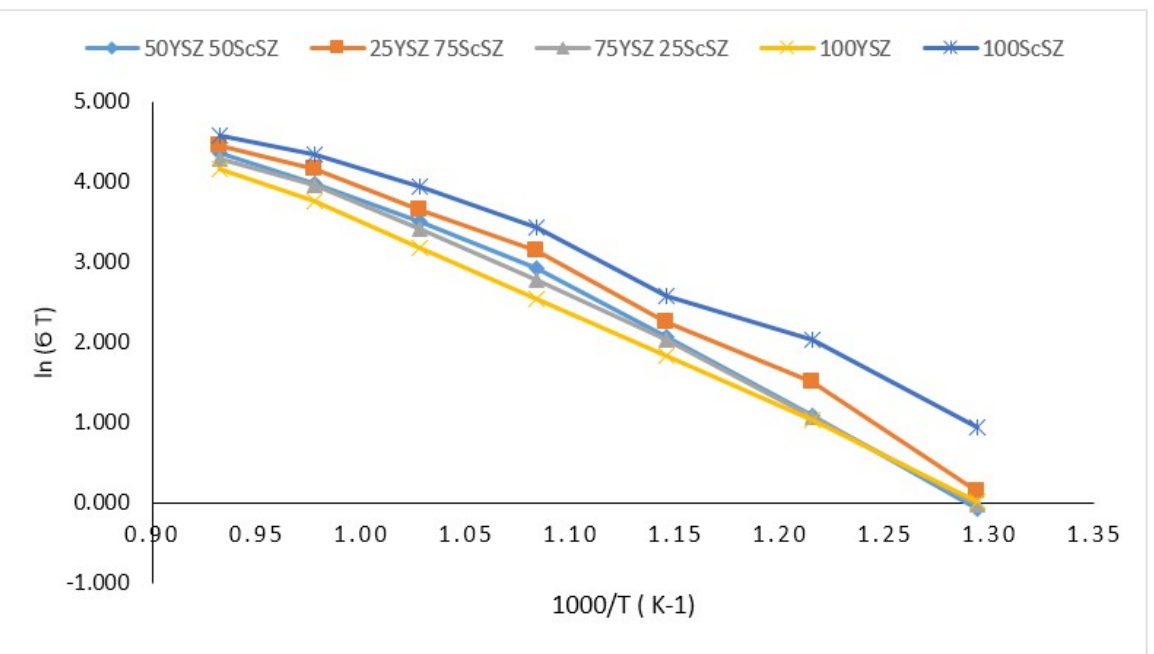

Figure 4 - Arrhenius plots under $1550{ }^{\circ} \mathrm{C}$ sintering temperature.

Figure 3 shows that the pellets with 25YSZ: $75 \mathrm{ScSZ}$ ratio has the highest ionic conductivity after being subjected to sintering temperature of $1450^{\circ} \mathrm{C}$. On the other hand, Figure 4 shows that the pellets with $100 \mathrm{ScSZ}$ has the highest ionic conductivity after being subjected to sintering temperature of $1550^{\circ} \mathrm{C}$. These behavior shows that pellets that contain more ScSZ dominated the high ionic conductivity trend line. Based on the Arrhenius plot shown in Figures 2-4 above, the pellet with $25 \% \mathrm{YSZ}$ : $75 \% \mathrm{ScSZ}$ composition has the most stable increasing ionic conductivity with rising temperature, while other compositions show mostly fluctuating result. This is probably due to its improved microstructure and density. The activation energy (Ea) was calculated from the slope of the Arrhenius plot and the result was found to be $0.81 \mathrm{eV}$ which is in good agreement with other activation energy values for solid electrolyte previously reported [34], [35]. The surface view and cross sectional images of the pellet with $25 \% \mathrm{YSZ}$ : $75 \% \mathrm{ScSZ}$ composition sintered at different temperatures are shows in Figures 5-8.
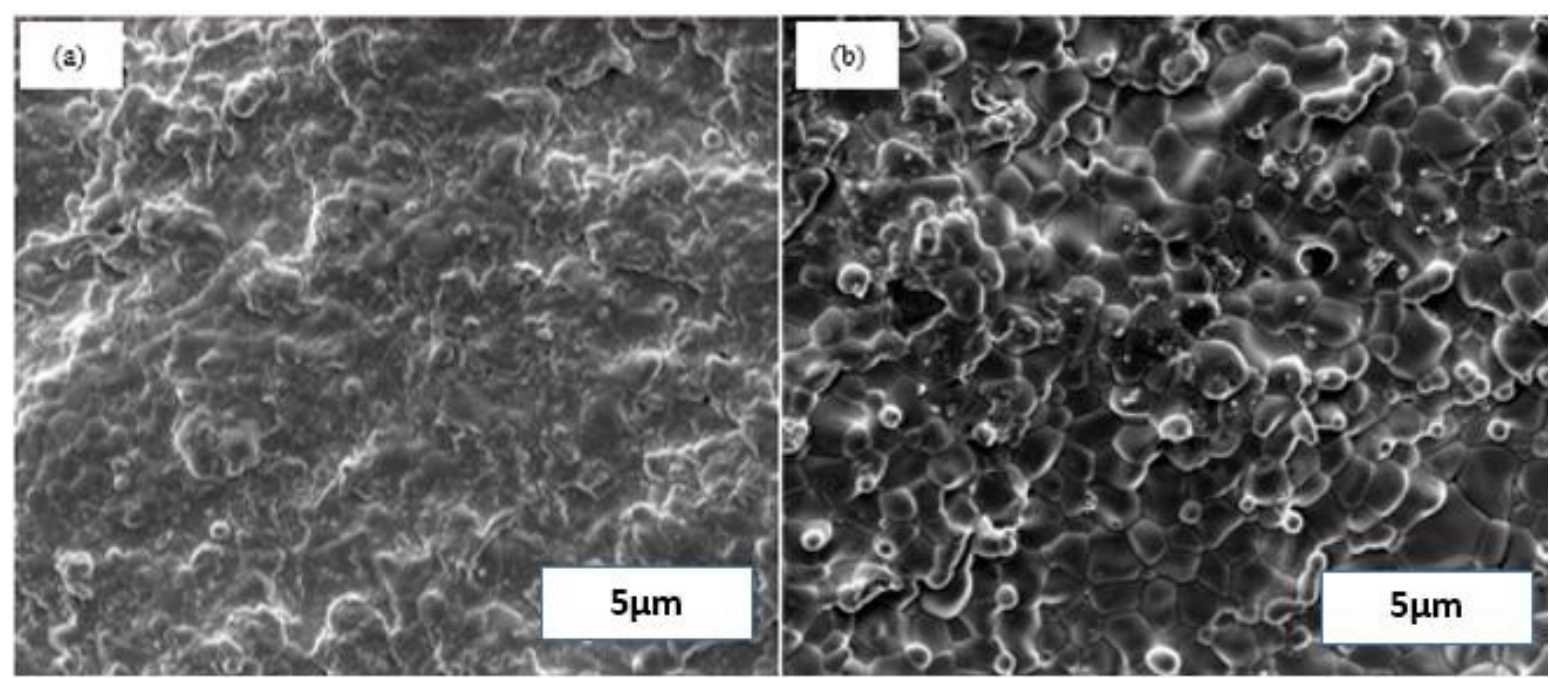

Figure 5 - Surface view of the pellets with $25 \%$ YSZ: $75 \% \mathrm{ScSZ}$ composition sintered at $\left(1350^{\circ} \mathrm{C}\right)$ in which (a) YSZ side and (b) ScSZ side.

Figures 5-7 clearly show that with the increasing of sintering temperature which is from $1350{ }^{\circ} \mathrm{C}$ to $1550{ }^{\circ} \mathrm{C}$, the porosity of the pellets are decreasing. In contrary, the grain size of the pellets are increases with sintering temperature. The results were further compared and verified by the relative densities of the sintered pellets. The relative densities were found to be $95 \%, 95 \%$ and $96 \%$ for $25 \% \mathrm{YSZ}$ : $75 \% \mathrm{ScSZ}$ pellets sintered at $1350{ }^{\circ} \mathrm{C}, 1450{ }^{\circ} \mathrm{C}$ and $1550{ }^{\circ} \mathrm{C}$ respectively. 
The bi-layering of YSZ and ScSZ can be clearly seen at 3000x magnification as per shown in Figure 8(a). The layer then is further studied under high magnification for both sides. The pellets were compared with $100 \%$ YSZ and $100 \% \mathrm{ScSZ}$ in order to see the change in microstructure and grain boundary for both materials, as per depicted in Figure 8 (b) and Figure 8 (c). As expected, both sides show different kind of microstructure and grain growth. It is confirmed that both materials are not doped or mixed together when fabricated via manual-pressed and cold-pressed method.

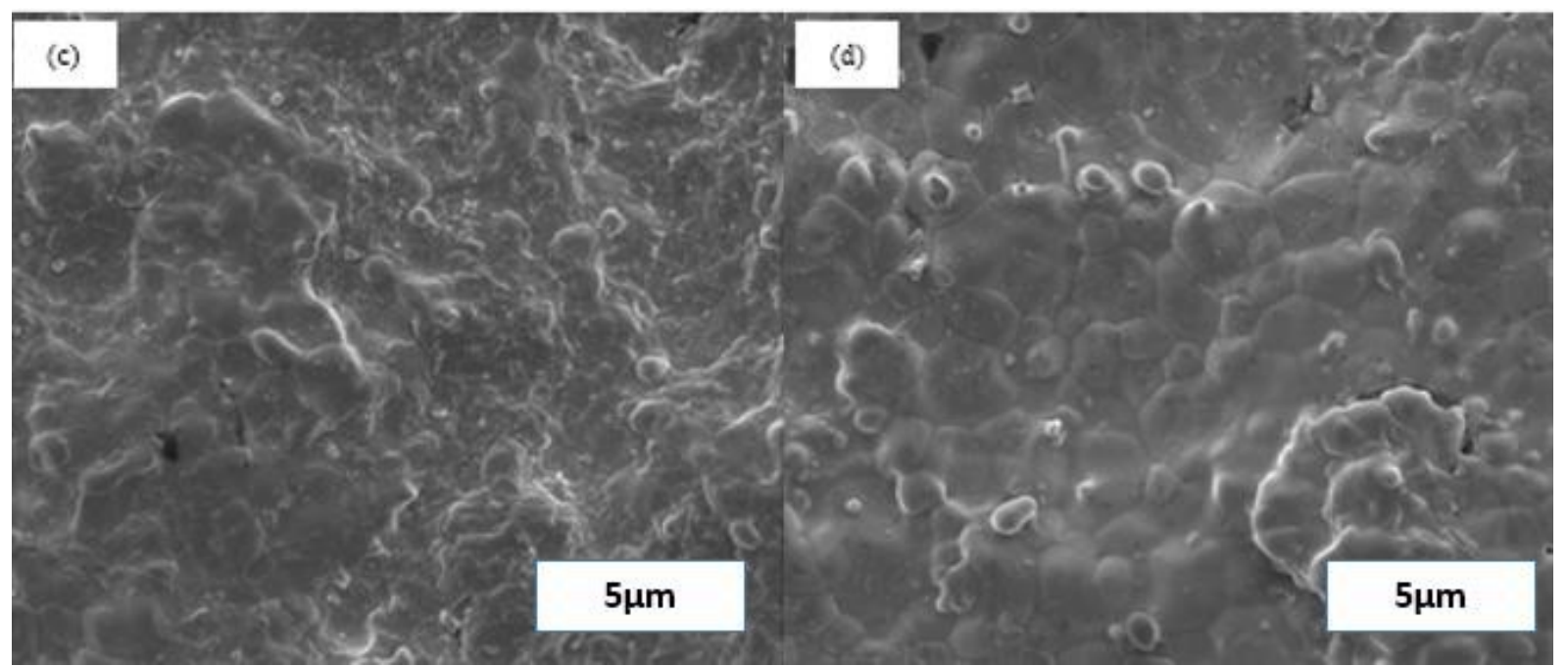

Figure 6 - Surface view of the pellets with $25 \%$ YSZ: $75 \% \mathrm{ScSZ}$ composition sintered at $\left(1450^{\circ} \mathrm{C}\right)$ in which $(\mathrm{c})$ YSZ side and (d) ScSZ side.

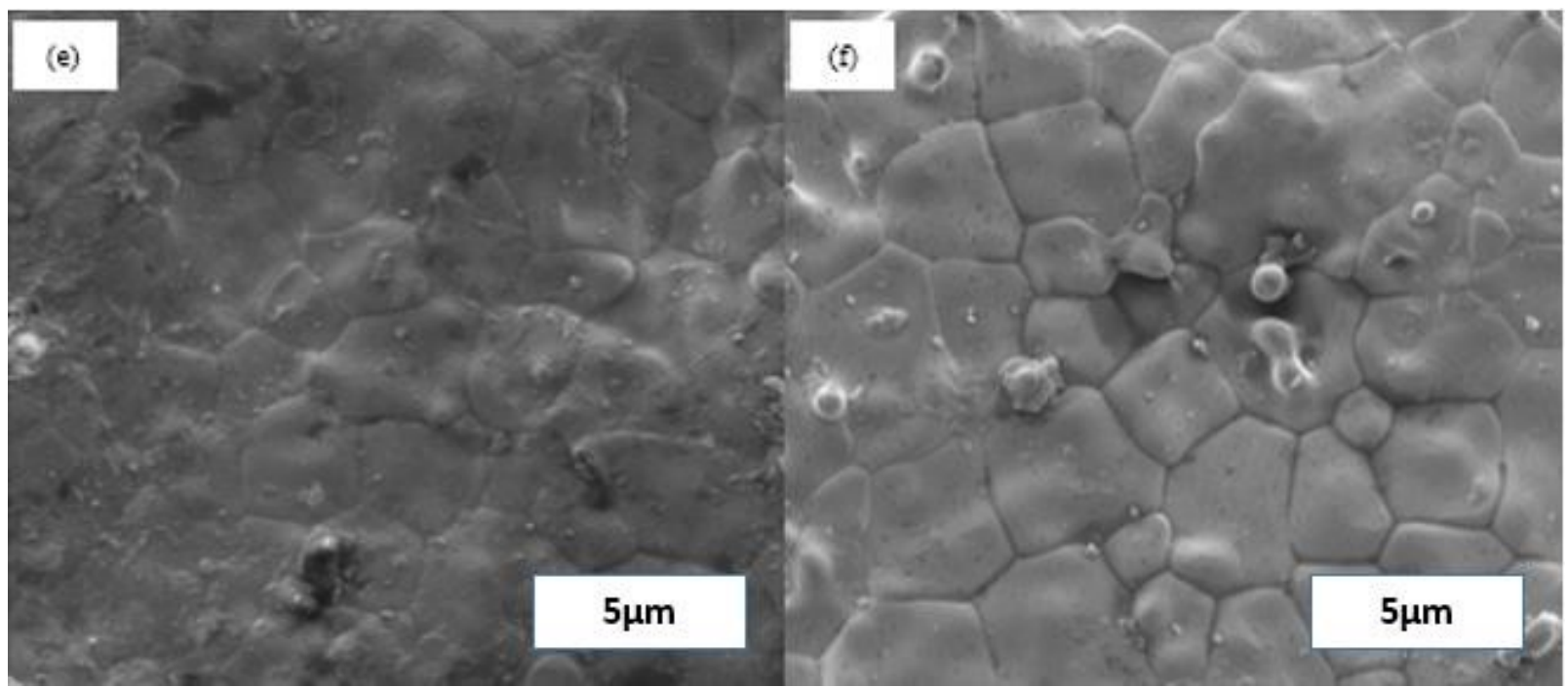

Figure 7 - Surface view of the pellets with $25 \%$ YSZ: $75 \% \mathrm{ScSZ}$ composition sintered at $\left(1550^{\circ} \mathrm{C}\right)$ in which (e) YSZ side and (f) ScSZ side.

\section{Conclusion and Recommendations}

In this paper, an experimental study of bilayer YSZ/ScSZ electrolyte of five different weight ratio has been presented. The YSZ/ScSZ bilayer electrolyte were fabricated using manual-pressed and cold iso-static pressed method followed by sintering process at different temperature. Archimedes method were used to determine the density of the pellets. The electrochemical behaviour and conductivities of the samples were studied in the temperature range of $500^{\circ} \mathrm{C}-800^{\circ} \mathrm{C}$ using EIS. The ionic conductivity of each pellet with difference weight ratio was observed to investigate the optimum composition and sintering temperatures. The microstructure and grain boundaries of all samples has also been studied using SEM. It is found that, based on this study, the best composition for YSZ/ScSZ bilayer electrolyte is 25\%YSZ: $75 \% \mathrm{ScSZ}$ pellet sintered at $1450^{\circ} \mathrm{C}$. Further studies on samples cubic phase and their influence on electrochemical results will be performed in the future. 


\section{Acknowledgement}

This paper is fully funded by TNB Seeding Fund under grant U-TV-RD-18-21.
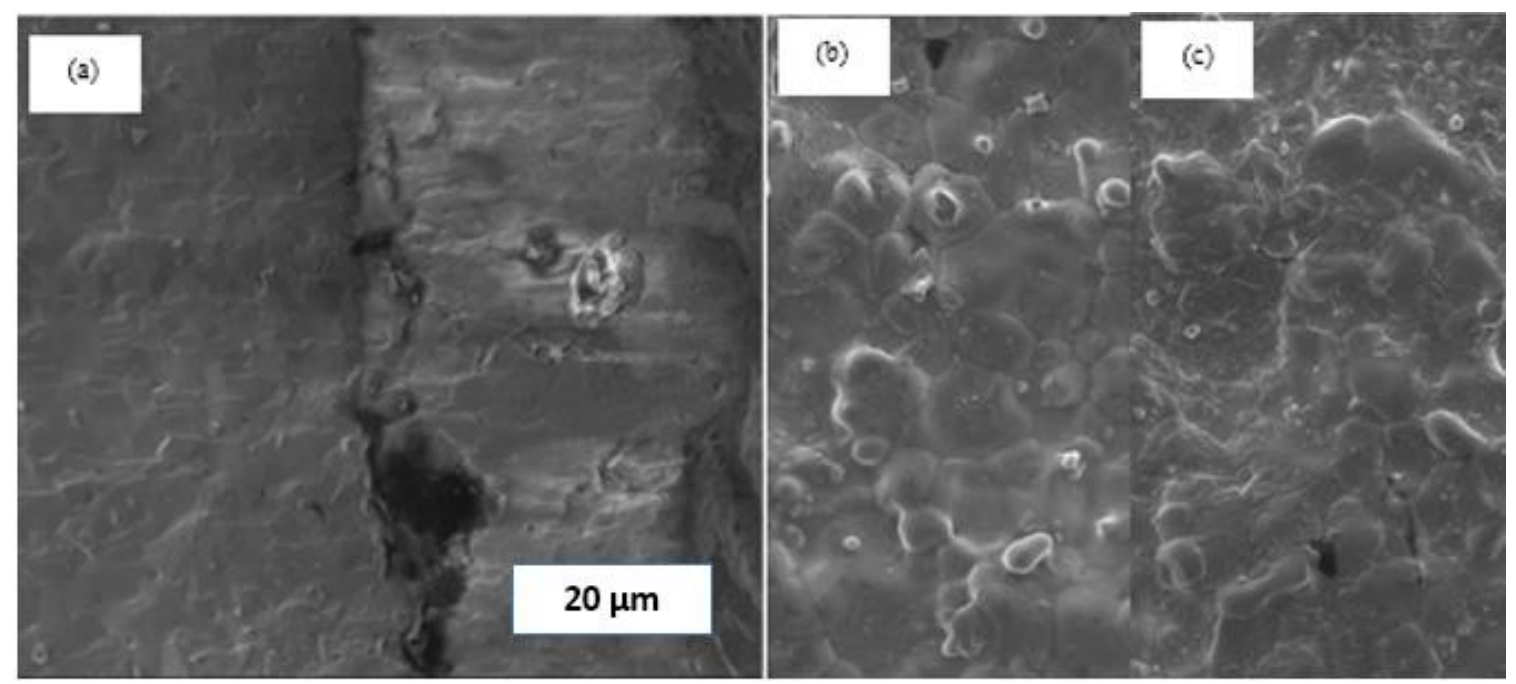

Figure 8 - Cross Sectional view of $25 \%$ YSZ: $75 \%$ ScSZ pellets sintered at $\left(1450^{\circ} \mathrm{C}\right)$ in which (a) Cross section of the bilayer, (b) YSZ side and (c) ScSZ side.

\section{References}

[1] N. Shaari, "Recent advances in additive - enhanced polymer electrolyte membrane properties in fuel cell applications : An overview," no. November 2018, 2019.

[2] N. Shaari and S. K. Kamarudin, "Enhanced mechanical flexibility and performance of sodium alginate polymer electrolyte bio-membrane for application in direct methanol fuel cell," vol. 46666, no. M, pp. 1-13, 2018.

[3] N. F. Raduwan, A. Muchtar, M. R. Somalu, A. Baharuddin, and M. A. Sa, "Challenges in Fabricating Solid Oxide Fuel Cell Stacks for Portable Applications : A Short Review,” vol. 10, pp. 80-86, 2018.

[4] N. Ashikin et al., "A short review on the modeling of solid-oxide fuel cells by using computational fluid dynamics : assumptions and boundary conditions," vol. 10, pp. 87-92, 2018.

[5] N. Q. Minh, "Solid oxide fuel cell technology - Features and applications," Solid State Ionics, vol. 174, no. 1-4, pp. 271-277, 2004.

[6] S. C. Singhal, "Solid oxide fuel cells for stationary, mobile, and military applications," Solid State Ionics, vol. 152-153, pp. 405-410, 2002.

[7] C. Cho and K. Lee, "Processing Research solid oxide fuel cells," vol. 14, no. 1, pp. 59-64, 2013.

[8] S. de Souza, "Thin-film solid oxide fuel cell with high performance at low-temperature," Solid State Ionics, vol. 98, no. 1-2, pp. 57-61, 1997.

[9] J. P. P. Huijsmans, F. P. F. Van Berkel, and G. M. Christie, "Intermediate temperature SOFC - A promise for the 21st century," J. Power Sources, vol. 71, no. 1-2, pp. 107-110, 1998.

[10] J.-W. Kim, "Polarization Effects in Intermediate Temperature, Anode-Supported Solid Oxide Fuel Cells," $J$. Electrochem. Soc., vol. 146, no. 1, p. 69, 1999.

[11] R. Maric, S. Ohara, T. Fukui, H. Yoshida, and M. Nishimura, “'Solid Oxide Fuel Cells with Doped Lanthanum Gallate Electrolyte and LaSrCoO3 Cathode, and Ni-Samaria-Doped Ceria Cermet Anode,"” vol. 146, no. 6, pp. 2006-2010, 1999.

[12] Y. Leng, S. Chan, S. Jiang, and K. Khor, "Low-temperature SOFC with thin film GDC electrolyte prepared in situ by solid-state reaction," Solid State Ionics, 2004.

[13] S. H. Chan, X. J. Chen, and K. A. Khor, "A simple bilayer electrolyte model for solid oxide fuel cells," Solid State Ionics, vol. 158, no. 1-2, pp. 29-43, 2003.

[14] A. Tsoga, A. Gupta, A. Naoumidis, and P. Nikolopoulos, "Gadolinia-doped ceria and yttria stabilized zirconia interfaces: Regarding their application for SOFC technology," Acta Mater., vol. 48, no. 18-19, pp. 4709-4714, 2000.

[15] H. Choi, G. Y. Cho, and S. W. Cha, "Fabrication and characterization of anode supported YSZ/GDC bilayer electrolyte SOFC using dry press process," Int. J. Precis. Eng. Manuf. - Green Technol., vol. 1, no. 2, pp. 9599, 2014.

[16] Q. L. Liu, S. H. Chan, C. J. Fu, and G. Pasciak, "Fabrication and characterization of large-size electrolyte/anode bilayer structures for low-temperature solid oxide fuel cell stack based on gadolinia-doped 
ceria electrolyte," Electrochem. commun., vol. 11, no. 4, pp. 871-874, 2009.

[17] J. Y. Park and E. D. Wachsman, "Stable and high conductivity ceria/bismuth oxide bilayer electrolytes for lower temperature solid oxide fuel cells," Ionics (Kiel)., vol. 12, no. 1, pp. 15-20, 2006.

[18] P. Sharma, S. K1, and S. Ap, “A Study on the Present Status of Zirconia based Electrolytes for Solid Oxide Fuel Cell," vol. 4, no. 3, pp. 23-26, 2016.

[19] D. Panthi, B. Choi, and A. Tsutsumi, "Fabrication and Evaluation of a Micro-Tubular Solid Oxide Fuel Cell with an Inert Support Using Scandia-Stabilized Zirconia Electrolyte,” J. Electrochem. Soc., vol. 162, no. 14, pp. F1555-F1560, 2015.

[20] Q. XUE, X. HUANG, H. ZHANG, H. XU, J. ZHANG, and L. WANG, "Synthesis and characterization of high ionic conductivity ScSZ core/shell nanocomposites," J. Rare Earths, vol. 35, no. 6, pp. 567-573, 2017.

[21] J. Patakangas, Y. Ma, Y. Jing, and P. Lund, "Review and analysis of characterization methods and ionic conductivities for low-temperature solid oxide fuel cells (LT-SOFC)," J. Power Sources, vol. 263, pp. 315331, Oct. 2014.

[22] X. Zhang, "Influence of architecture, materials, and processing on low temperature solid oxide fuel cell (LTSOFC) performance," Jan. 2009.

[23] S. P. S. Badwal, F. T. Ciacchi, and D. Milosevic, "Scandia-zirconia electrolytes for intermediate temperature solid oxide fuel cell operation," Solid State Ionics, vol. 136-137, pp. 91-99, 2000.

[24] A. Spirin, V. Ivanov, A. Nikonov, A. Lipilin, S. Paranin, and V. Khrustov, "Scandia-stabilized zirconia doped with yttria : Synthesis, properties, and ageing behavior," vol. 225, pp. 448-452, 2012.

[25] M. A. Laguna-Bercero, "Recent advances in high temperature electrolysis using solid oxide fuel cells: A review," J. Power Sources, vol. 203, pp. 4-16, 2012.

[26] Y. Chen et al., "Layered YSZ/SCSZ/YSZ electrolytes for intermediate temperature SOFC Part I: Design and manufacturing," Fuel Cells, vol. 12, no. 5, pp. 722-731, 2012.

[27] Q. L. Liu, K. A. Khor, S. H. Chan, and X. J. Chen, “Anode-supported solid oxide fuel cell with yttria-stabilized zirconia/gadolinia-doped ceria bilalyer electrolyte prepared by wet ceramic co-sintering process," J. Power Sources, vol. 162, no. 2 SPEC. ISS., pp. 1036-1042, 2006.

[28] B. Shri Prakash, R. Pavitra, S. Senthil Kumar, and S. T. Aruna, "Electrolyte bi-layering strategy to improve the performance of an intermediate temperature solid oxide fuel cell: A review," J. Power Sources, vol. 381 , no. February, pp. 136-155, 2018.

[29] Y. Jee et al., "High performance Bi-layered electrolytes via atomic layer deposition for solid oxide fuel cells," J. Power Sources, vol. 253, pp. 114-122, May 2014.

[30] X. Zhang, M. Robertson, and C. Decès-petit, ") and bi-layered electrolyte of the SDC layer with proton conducting ceramic material BCY (BaCe 0.9 Y 0.1 O,” vol. 78, no. 1, pp. 429-439, 2017.

[31] A. Kumar, A. Jaiswal, M. Sanbui, and S. Omar, "Scripta Materialia Scandia stabilized zirconia-ceria solid electrolyte ( x Sc1CeSZ , 5 b x b 11 ) for IT-SOFCs : Structure and conductivity studies," SMM, vol. 121, pp. $10-13,2016$.

[32] T. Mahata, S. R. Nair, R. K. Lenka, and P. K. Sinha, "Fabrication of Ni-YSZ anode supported tubular SOFC through iso-pressing and co-firing route," Int. J. Hydrogen Energy, vol. 37, no. 4, pp. 3874-3882, 2012.

[33] A. Azim et al., "Enhanced ionic conductivity of scandia-ceria-stabilized-zirconia ( $10 \mathrm{Sc} 1 \mathrm{CeSZ})$ electrolyte synthesized by the microwave-assisted glycine nitrate process," Ceram. Int., no. March, pp. 1-7, 2017.

[34] S. J. Skinner and J. A. Kilner, "Performance of solid oxide electrolysis cells based on scandia stabilised zirconia," vol. 192, pp. 126-131, 2009.

[35] L. Besra, S. Zha, and M. Liu, "Preparation of NiO-YSZ / YSZ bi-layers for solid oxide fuel cells by electrophoretic deposition," vol. 160, pp. 207-214, 2006. 